\title{
The Influence of Choice Theory Anger Management Program (CTAMP) on the Ability of Prospective Psychological Counselors for Anger Management
}

\author{
Rezzan Gündoğdu ${ }^{1}$ \\ ${ }^{1}$ Department of Psychological Counseling and Guidance Aksaray University, Aksaray, Turkey \\ Correspondence: Rezzan Gündoğdu, Psychological Counseling and Guidance Aksaray University, Aksaray, \\ Turkey. Tel: 90-534-560-3306. E-mail: gundogdurezzan@hotmail.com
}

Received: December 1, 2017

Accepted: January 12, 2018

Online Published: March 28, 2018

doi:10.5539/ies.v11n4p43

URL: https://doi.org/10.5539/ies.v11n4p43

\begin{abstract}
This research is a quasi-experimental study with pretest-posttest-fallow up test and experiment-control group to investigate the influence of Choice Theory-based Anger Management Psychoeducation Program (CTAMP) on the ability of students of Department of Psychological Counseling and Guidance (PCG) for anger management. The Trait Anger-Anger Style Scale was used for the dependent variable. 40 students were identified as eligible to participate in the study based on the scores from subscales of STAS. Then a total of 18 volunteer students (14 females and 5 males) were identified that had time to participate in activities. The control group included 19 students (14 females, 5 males). The CTAMP was administrated to the experimental group for twelve weeks, and no procedures were performed for the control group. Then, reminder sessions were held for 3 more weeks for the control group and the final follow-up measurement was taken. The data was analyzed by SPSS 18 packet program. The t-test was performed to find the differences between the follow up pretest-follow up posttest scores in the experimental and control groups, and ANOVA was carried out to find the within-group differences for repeated measurements. At the end of CTAMP that lasted 12 weeks, it is observed that the trait anger-anger, anger-in and anger-out scores for the experimental group were reduced from the pretest to posttest, but the anger control scores were increased. At the end of follow-up sessions, the variance in the scores was similar.
\end{abstract}

Keywords: psychoeducation, university students, experimental study, anger management

\section{Introduction}

According to Novaco, a researcher doing research on the concept of anger, the concept of anger had not been seen as a problem for a very long term in the field of psychology (Özmen, 2004). It is due to the fact that the anger had been addressed as a dimension of the concept of aggressiveness for years. Individuals make a subjective evaluation and feel bad in anger, and they make a social evaluation and perceive the anger as a negative emotion based on the consideration that angry persons are not liked (Kassinove \& Sukhodolsky, 1995). The idea that expression of anger is negative not the anger itself has recently gained acceptance (Şahin, 2004). The researchers such as Ellis (1977), Schurger (1979), Efron (1997), Köknel (1999), Olatunji, Lohr, and Bushman (2007) and E. Harmon-Jones and C. Harmon-Jones (2007) emphasize that the anger is adaptive and functional that facilitates to defend oneself in case of a threat.

At this point, Glasser (2000) thinks that individuals who have problems with interpersonal relations should head for realistic choices that would release the relationship from obstruction. Thus, individuals should learn about the choice theory. In the choice theory, individuals have a background to control their behavior. According to Glasser (2000) the feeling of "anger" may occur when the individuals try to control the other individuals not themselves.

The psychoeducational activities may be carried out to cope with anger and teach individuals to improve life skills and develop new solutions to problems. According to McWhirter \& Page (1999) the psychoeducation-focused groups in relation to the anger are especially effective in the form of expression of emotion of anger.

Previous studies (Bilge, 1996; Özmen, 2004; Özkamalı \& Buga, 2010; Öz \& Aysan, 2012; Karahan, Yalçın, \& Erbaş, 2014; Rahmatulin, 2015; Deffenbacher, McNamara, Stark, \& Sabadel, 1990; Deffenbacher \& Stark, 1992; Deffenbacher, Lynch, Oetting, \& Kemper, 1996; Herrman \& McWhirter, 2003; Zajenkowski \& Zajenkowska, 2015 ) indicated that a variety of programs developed for reducing and controlling anger have been effective in 
anger. Since the angry individuals do not know how to act otherwise, they continue to act with anger (Efron, 1997). It is observed that group studies using different methods or various psychoeducation groups have positive effects on coping with anger by individuals. In the research, anger control programs developed mostly for adolescent groups. Interestingly, there are only few studies performed on university students studying in the psychological counseling and guidance program. Therefore, this research is considered to fill a gap in the field.

\section{Methods}

\subsection{Research Design}

The objective of this study was to investigate the influence of CTAMP that developed and used by the researcher for the students of department of PCG, on the students' skill for anger management. A model with pretest, posttest, follow-up test and control group was used for the research. The design with pretest, posttest, follow-up test and control group is a complex design that is widely used. The participants are measures for dependent variable before and after the experimental procedure (Büyüköztürk, 2007, p. 19). This research used a control group to show that variation that might occur in the group participated in CTAMP was due to the program used. The research has a 2x4 split-plot design including complex measurements. An experimental design with pretest, posttest, pre-follow-up-post-follow-up test measurement was used for the experimental group participated in CTAMP and the control group that did not participate in the program based on the scores from trait anger-anger style scale. In this design, first factor is to show experimental design groups (experiment-control), and the second factors is to show repeated measurements for the dependent variable (pretest, posttest, pre-follow-up and post-follow-up test). This research used a control group to show that variation that might occur in the group participated in CTAMP was due to the program used. The quantitative data from STAS was analyzed by SPSS 18 computer program.

\subsection{Study Group}

A "Personal Information Form" and STAS adapted to Turkish by Ozer (1994b) were used to form the control and experimental groups of research. The scale was administrated by the researcher to a total of 91 volunteer students (64 female and 27 male students) studying in the Psychological Counseling and Guidance (PCG) undergraduate program in the 2015-2016 academic. The number of female students was greater than the number of male students studying in the PCG undergraduate program. This was considered to form the experimental and control groups. 40 students were identified as eligible to participate in the study based on the scores from subscales of STAS. Then a total of 18 volunteer students ( 14 females and 5 males) were identified that had time to participate in activities. The control group included 19 students (14 females, 5 males). Initially, each group had 19 students, but the data of 18 students were analyzed in the experimental group because 1 student in this group went to a different university for education. Table 1 shows the standard deviation and the arithmetic mean of STAS pre-post-follow up scores for the experimental and control groups. 
Table 1. Arithmetic mean of scores of research groups for trait anger-anger style scale by pre-post-follow-up measurements and the standard deviation

\begin{tabular}{|c|c|c|c|c|c|c|}
\hline \multirow{2}{*}{$\begin{array}{l}\text { Groups } \\
\text { Measurements }\end{array}$} & \multicolumn{3}{|c|}{ Experimental } & \multicolumn{3}{|c|}{ Control } \\
\hline & $\mathrm{N}$ & $\overline{\bar{X}}$ & SD & $\mathrm{N}$ & $\overline{\bar{X}}$ & $\mathrm{SD}$ \\
\hline \multicolumn{7}{|l|}{ STAS-Pretest } \\
\hline Trait Anger & 18 & 22.33 & 4.84 & 19 & 22.37 & 3.98 \\
\hline Anger Control & 18 & 20.94 & 4.61 & 19 & 20.00 & 3.71 \\
\hline Anger-out & 18 & 17.22 & 4.70 & 19 & 18.21 & 2.84 \\
\hline Anger-in & 18 & 19.28 & 3.67 & 19 & 18.16 & 2.93 \\
\hline \multicolumn{7}{|l|}{ STAS-Posttest } \\
\hline Trait Anger & 18 & 19.00 & 3.65 & 19 & 22.16 & 3.32 \\
\hline Anger Control & 18 & 24.89 & 3.38 & 19 & 21.79 & 3.55 \\
\hline Anger-out & 18 & 17.22 & 4.03 & 19 & 17.05 & 3.34 \\
\hline Anger-in & 18 & 17.33 & 3.36 & 19 & 19.26 & 2.76 \\
\hline \multicolumn{7}{|c|}{ STAS-Follow-up Pretest } \\
\hline Trait Anger & 18 & 18.83 & 3.33 & 19 & 21.26 & 3.97 \\
\hline Anger Control & 18 & 23.55 & 4.17 & 19 & 22.42 & 4.35 \\
\hline Anger-out & 18 & 16.67 & 3.94 & 19 & 17.37 & 4.03 \\
\hline Anger-in & 18 & 19.28 & 3.67 & 19 & 18.16 & 2.93 \\
\hline \multicolumn{7}{|c|}{ STAS-Follow-up Posttest } \\
\hline Trait Anger & 18 & 16.78 & 2.69 & 19 & 20.58 & 3.92 \\
\hline Anger Control & 18 & 24.55 & 2.59 & 19 & 22.37 & 3.89 \\
\hline Anger-out & 18 & 15.05 & 2.53 & 19 & 16.63 & 3.11 \\
\hline Anger-in & 18 & 17.05 & 3.35 & 19 & 19.42 & 2.91 \\
\hline
\end{tabular}

In Table 1, the arithmetic means of pre-measurement scores for the experimental and control groups are similar. Firstly, it was checked that whether the scores achieved the assumption of parametric measurements to decide on the statistical analysis method for the data as the number of participants in the experimental group and control group was less than 30. The Kolmogorov-Smirnov Test and the Skewness Test were performed to determine whether the scores from trait anger, anger control, anger-in and anger-out pretest posttest, pre-follow-up and post-follow-up scales were normally distributed. If the scores are $\mathrm{p}<.05$ in the Kolmogorov-Smirnov Test, this indicates a normal distribution (Büyüköztürk, 2008). The Kolmogorov-Smirnov analysis gave a value greater than $\mathrm{p}<.05$. This shows that scores from all procedures were normally distributed. The value for Skewness was also smaller than 1. If the Skewness values range +1 to -1 , this indicates a normal distribution (Büyüköztürk, 2008). The Levene Test was performed to test whether the groups were homogenous. If the scores are greater than $\mathrm{p}<.05$ in the Levene Test, this means that the groups are heterogenous not homogenous. The results of Levene Test show that the experimental and control groups were not homogenous, i.e., they had heterogenous distribution (Çokluk, Şekercioğlu, \& Büyüköztürk, 2010). Based on this, parametric measurements were used for this research.

\subsection{Research Instruments and Procedure}

To measure the dependent variable, the scale originally called The State Trait Anger Scale (STAS) developed by Charles D. Spielberger, Jacobs, Russel and Crane between 1980 and 1983 was used to determine the level of anger of students. This scale addresses the emotion and expression of anger in terms of state and trait. This is a four point likert scale, and of 20 items, 10 were developed to measure the state anger and 10 were developed to measure the trait anger. Each subtest had its own score. The individuals may get a score 8 to 32 as the sum of each sub-dimension of Anger Expression Style Scale. A high score indicates a tendency to high anger for that subtest. The low score for trait anger, anger-in and anger-out and the high score for anger control are considered positive. There is no a total score for the scale (Savaşır \& Şahin, 1997). STAS consists of 4 subtests, they are trait anger, anger-in, anger-out and anger control subtests (Savaşır \& Şahin, 1997, pp. 71-72; Özmen, 2004).

\subsection{Experimental Application}

The CTAMP developed by the researcher is a psychoeducational program based on the choice theory. 12 sessions were scheduled with each session lasting 90-120 minutes. This program was intended to enable students to raise awareness regarding changes in emotions and thoughts and physiological changes, to notice angry behaviors, to 
realize their choices, to increase proper behaviors in interpersonal relationships, to express any emotions experienced and behaviors in an acceptable way, to properly express their emotions and feel relaxed, and to learn how to control their body.

\section{Results}

Parametric measurements were made based on the scores from data. For independent samples, $\mathrm{t}$ test was performed to compare the differences in mean of scores for the trait anger, anger control, anger-in and anger-out pretest posttest, pre-follow-up and post-follow-up in the experimental and control groups.

Table 2. T-Test for experimental and control groups

\begin{tabular}{|c|c|c|c|c|c|c|c|c|}
\hline Subscales & Groups & $\mathrm{N}$ & $\bar{X}$ & Levene & $\mathrm{S}$ & $\mathrm{Sd}$ & $\mathrm{t}$ & $\mathrm{P}$ \\
\hline \multicolumn{9}{|l|}{ Pretests } \\
\hline \multirow{2}{*}{ Trait anger } & Exp. & 18 & 22.33 & & 4.84 & \multirow{2}{*}{35} & \multirow{2}{*}{.02} & \multirow{2}{*}{.98} \\
\hline & Control & 19 & 22.37 & .202 & 3.99 & & & \\
\hline \multirow{2}{*}{ Anger control } & Exp. & 18 & 20.94 & & 4.61 & \multirow{2}{*}{35} & \multirow{2}{*}{-.69} & \multirow{2}{*}{.500} \\
\hline & Control & 19 & 20.00 & .812 & 3.71 & & & \\
\hline \multirow{2}{*}{ Anger-out } & Exp. & 18 & 17.22 & & 2.84 & \multirow{2}{*}{35} & \multirow{2}{*}{.78} & \multirow{2}{*}{.44} \\
\hline & Control & 19 & 18.21 & .074 & 4.70 & & & \\
\hline \multirow{2}{*}{ Anger-in } & Exp. & 18 & 19.28 & & 3.67 & \multirow{2}{*}{35} & \multirow{2}{*}{-1.03} & \multirow{2}{*}{.311} \\
\hline & Control & 19 & 18.16 & .277 & 2.93 & & & \\
\hline \multicolumn{9}{|l|}{ Posttest } \\
\hline \multirow{2}{*}{ Trait anger } & Exp. & 18 & 19.00 & & 3.65 & \multirow{2}{*}{35} & \multirow{2}{*}{2.76} & \multirow{2}{*}{.005} \\
\hline & Control & 19 & 22.16 & .764 & 3.32 & & & \\
\hline \multirow{2}{*}{ Anger control } & Exp. & 18 & 24.89 & & 3.55 & \multirow{2}{*}{35} & \multirow{2}{*}{-2.72} & \multirow[t]{2}{*}{.010} \\
\hline & Control & 19 & 21.79 & .708 & 3.38 & & & \\
\hline Anger-out & Exp. & 18 & 17.22 & & 4.04 & & & \\
\hline Anger-out & Control & 19 & 17.05 & .864 & 3.34 & 35 & -.14 & .890 \\
\hline Anoer-in & Exp. & 18 & 17.33 & & 3.36 & 35 & 191 & 064 \\
\hline Anger-1n & Control & 19 & 19.26 & .722 & 2.76 & 35 & 1.91 & .064 \\
\hline Follow-up pret & & & & & & & & \\
\hline Trait anoer & Exp. & 18 & 18.83 & & 3.33 & 35 & 201 & 052 \\
\hline I rait anger & Control & 19 & 21.26 & .546 & 3.97 & 35 & 2.01 & .052 \\
\hline Anger control & Exp. & 18 & 23.55 & & 4.17 & 35 & 808 & 424 \\
\hline Anger control & Control & 19 & 22.42 & .781 & 4.35 & 35 & -.808 & .424 \\
\hline Anori-out & Exp. & 18 & 16.67 & & 3.94 & 35 & 535 & 506 \\
\hline Anger-out & Control & 19 & 17.37 & .898 & 4.03 & 35 & (353 & . \\
\hline Anger-in & Exp. & 18 & 19.28 & & 3.67 & 35 & 103 & 311 \\
\hline Anger-1n & Control & 19 & 18.16 & .277 & 2.93 & 35 & -1.03 & .311 \\
\hline Follow-up pos & & & & & & & & \\
\hline Trait anger & Exp. & 18 & 16.78 & & 2.69 & 35 & 342 & 002 \\
\hline Trait anger & Control & 19 & 20.58 & .083 & 3.92 & 35 & 3.42 & .002 \\
\hline Anoer control & Exp. & 18 & 24.56 & & 2.59 & 35 & -200 & 053 \\
\hline & Control & 19 & 22.37 & .093 & 3.89 & & & \\
\hline A nocrout & Exp. & 18 & 15.05 & & 2.53 & 25 & 168 & 101 \\
\hline Anger-oul & Control & 19 & 16.63 & .612 & 3.11 & 35 & 1.08 & .101 \\
\hline Ancrin & Exp. & 18 & 17.05 & & 3.35 & 35 & 229 & 028 \\
\hline Anger-1n & Control & 19 & 19.42 & .343 & 2.91 & 35 & 2.29 & .028 \\
\hline
\end{tabular}

As seen in Table 2, Levene Test in the experimental and control groups was greater than $p<.05$. This indicates that groups were heterogenous. According to the results of $t$ test, the anger scores for the experimental and control groups were examined before starting the experimental process. No significant differences were found in the mean of scores for trait anger $(\mathrm{t}=.24 ; \mathrm{F}=1.694, \mathrm{P}<0.05)$, anger control $(\mathrm{t}=-.684 ; \mathrm{F}=058, \mathrm{P}<0.05)$, anger-out $(\mathrm{t}=.769$; $\mathrm{F}=3.391, \mathrm{P}<0.05)$ and anger-in $(\mathrm{t}=-2.021 ; \mathrm{F}=1.219, \mathrm{P}<0.05)$ pretests. Based on this, experimental process was started with trait anger style expression being the same for the experimental and control groups.

The results show that there was a significant difference in the trait anger scores and the pretest scores between the 
experimental and control groups $(\mathrm{t}=2.750 ; \mathrm{F}=.91 \mathrm{P}<0.05)$. The mean of scores for the experimental group was lower and the mean of scores for the control group was higher $(\bar{X}$ exp. $=19.00<\bar{X}$ control=22.15). In addition, there was a reduction between the trait anger scores and pretest and posttest scores for the experimental group after the experimental process ( $\bar{X}$ exp. pretest $=22.33>\bar{X}$ exp. posttest $=19.00 ; \mathrm{t}=2.257$ ). This may be interpreted that the experimental process was effective in reducing trait anger scores.

The results of $\mathrm{t}$ test shows a significant difference in the anger control scores for the experimental and control groups ( $\mathrm{t}=2.717 ; \mathrm{F}=.143 \mathrm{P}<0.05)$. The mean of scores was higher in the experimental group, and the mean of scores for the control group was lower $(\bar{X}$ exp. posttest $=24.88>\bar{X}$ control posttest $=21.78 ; \mathrm{t}=2.257)$. This may be interpreted that the experimental process increased the anger control scores.

The results of $\mathrm{t}$ test indicates no significant difference in the anger-out scores for the experimental and control groups $(\mathrm{t}=-.139 ; \mathrm{F}=030, \mathrm{P}<0.05)$ and in the anger-in scores $(\mathrm{t}=1.901 ; \mathrm{F}=.129 ; \mathrm{P}<0.05)$.

The results of $\mathrm{t}$ test show a significant difference in the initial follow-up trait anger scores for the experimental and control groups ( $\mathrm{t}=2.021 ; \mathrm{F}=.372 ; \mathrm{P}<0.05)$. The mean of scores was lower in the experimental group and the mean of scores was higher in the control group $(\bar{X}$ exp. pre-follow-up test $=18.83<\bar{X}$ control pre-follow-up test $=21.26$ ). This may indicate that the experimental process was still effective in reducing the trait anger.

The results indicate no significant differences in the mean of scores for initial follow-up anger control $(\mathrm{t}=-.809$; $\mathrm{F}=.079 ; \mathrm{P}<0.05)$, anger-out $(\mathrm{t}=.535 ; \mathrm{F}=.017 ; \mathrm{P}<0.05)$ and anger-in $(\mathrm{t}=-1.021 ; \mathrm{F}=1.219 ; \mathrm{P}<0.05)$ in the experimental and control groups.

After the 3-week follow-up sessions, the final follow-up measurements were made. According to the results, there was a significant difference in the final follow-up trait anger scores $(\mathrm{t}=3.454 ; \mathrm{F}=3.192 ; \mathrm{P}<0.05)$ in the experimental and control groups. The trait anger scores for the experimental group were lower than the trait anger scores for the control group control ( $\bar{X}$ exp. follow-up posttest $=16.67<\bar{X}$ control follow-up posttest $=20.57$ ). This indicates that follow-up sessions continued to reduce the trait anger scores in the long term.

The results show a significant difference in the mean of scores for final follow-up anger control $(\mathrm{t}=-2.022$; $\mathrm{F}=2.977 ; \mathrm{P}<0.05)$ in the experimental and control groups. The anger control scores for the experimental group were higher than that of control group ( $\bar{X}$ exp. follow-up posttest $=24.55>\bar{X}$ control follow-up posttest $=22.36$ ). This indicates that follow-up sessions continue to increase the anger control scores in the long term.

In the results of anger-in analysis, a significant difference was found in the mean of scores for anger-in $(\mathrm{t}=2.286$; $\mathrm{F}=923 ; \mathrm{P}<0.05)$ after the follow-up posttest in the experimental and control groups. The experimental group had lower anger-in scores for anger-in that the control group ( $\bar{X}$ exp. follow-up posttest $=17.05<\bar{X}$ control follow-up posttest $=19.42$ ). This indicates that follow-up sessions continued to reduce the anger-in scores in the long term.

The results of T- test analysis shows no significant difference in the mean of scores for follow-up posttest anger-out in the experimental and control groups $(\mathrm{t}=1.694 ; \mathrm{F}=.262 ; \mathrm{P}<0.05)$. For repeated measurements, ANOVA was performed to test the whether there were any differences in the pretest, posttest, pre-follow-up and post-follow-up tests.

Table 3. STAS-ANOVA results for pretest-posttest and pre-post follow-up test scores for trait anger sub-dimension

\begin{tabular}{cccccc}
\hline Source of variance & Sum of squares & SD & Mean of squares & F & P \\
\hline Peer-to-peer & 421.236 & 17 & 24.779 & 1075.203 & .000 \\
Ölçüm & 285.375 & 3 & 95.125 & 9.43 & .000 \\
Error & 514.375 & 51 & 10.086 & & \\
Total & 1.220 .986 & 71 & & & \\
\hline
\end{tabular}

There were significant differences in the pretest, posttest, follow-up pretest and follow-up posttest scores of participants for STAS-Trait Anger sub-dimension $(\mathrm{F}(3-51)=9.43, \mathrm{p}<.01)$. The mean of scores for posttest $(\bar{X}$ $=19.00)$, mean of scores for follow-up pretest $(\bar{X}=18.83)$ and follow-up posttest $(\bar{X}=16.78)$ was lower than the mean of scores for pretest $(\bar{X}=22.33)$. This finding indicates that trait anger scores of students participated in CTAMP were significantly reduced after the program and in the subsequent measurements; the trait anger scores after the program differed from the measurement results in the subsequent follow-up studies; and the influence of such difference was still present in the follow-up posttest. This indicates that the experimental process reduced the trait anger in the long term. 
Table 4. ANOVA results for pretest-posttest and pre-post follow-up test scores for STAS-anger control

\begin{tabular}{cccccc}
\hline Source of Variance & Sum of squares & SD & Mean of squares & F & P \\
\hline \multirow{2}{*}{ Peer-to-peer } & 569.736 & 17 & 33.514 & 1185.031 & .000 \\
& 172.575 & 3 & 57.458 & 7.402 & .001 \\
Error & 395.875 & 51 & 7.762 & & \\
Total & 1.137 .986 & 71 & & & \\
\hline
\end{tabular}

There were significant differences in the pretest, posttest, follow-up pretest and follow-up posttest scores of participants for STAS - Anger Control sub-dimension $(\mathrm{F}(3-51)=7.402, \mathrm{p}<.01)$. The mean of scores for posttest $(\bar{X}$ $=24.89)$, mean of scores for follow-up pretest $(\bar{X}=23.55)$ and mean of scores for follow-up posttest $(\bar{X}=24.55)$ were greater than the mean of scores for pretest $(\bar{X}=20.94)$. This finding indicates that anger control scores of students participated in CTAMP were significantly increased after the program and in the subsequent measurements; the anger control scores after the program differed from the measurement results in the subsequent follow-up studies, and the influence of such difference was still present in the follow-up posttest. This indicates that the experimental process increased the anger control in the long term.

Table 5. ANOVA results for pretest-posttest and pre-post follow-up test scores for STAS-anger-out sub-dimension

\begin{tabular}{cccccc}
\hline Source of Variance & Sum of squares & SD & Mean of Squares & F & P \\
\hline Peer-to-peer & 528.125 & 17 & 31.066 & 634.166 & .000 \\
Measurement & 58.708 & 3 & 18.903 & 1.940 & .000 \\
Error & 497.042 & 51 & 9.746 & & \\
Total & 1.083 .875 & 71 & & & \\
\hline
\end{tabular}

There were significant differences in the pretest, posttest, follow-up pretest and follow-up posttest scores of participants for STAS - Anger-out sub-dimension $(\mathrm{F}(3-51)=1.940, \mathrm{p}<.01)$. The mean of scores for posttest $(\bar{X}$ $=17.22)$ was the same as the mean of scores for pretest $(\bar{X}=17.22)$. The mean of scores for follow-up pretest $(\bar{X}=16.67)$ and the mean of scores for follow-up posttest $(\bar{X}=15.05)$ were lower than the mean of scores for pretest $(\bar{X}=17.22)$. This finding indicates that anger-out scores of students participated in CTAMP were significantly reduced in the follow-up measurements and subsequent final follow-up measurements; the anger-out scores after the program differed from the measurement results for subsequent follow-up studies, and the influence of such difference was still present in the follow-up posttest. This indicates that the experimental process reduced the anger-out scores in the long term.

Table 6. ANOVA results for pretest-posttest and pre-post follow-up test scores for STAS-anger-in sub-dimension

\begin{tabular}{cccccc}
\hline Source of Variance & Sum of Squares & SD & Mean of Squares & F & P \\
\hline Peer-to-peer & 416.236 & 17 & 24.484 & 977.926 & .000 \\
Measurement & 78.819 & 3 & 26.273 & 3.146 & .033 \\
Error & 425.931 & 51 & 8.352 & & \\
Total & 920.986 & 71 & & & \\
\hline
\end{tabular}

There were significant differences in the pretest, posttest, follow-up pretest and follow-up posttest scores of participants for TAASS-Anger-in sub-dimension $(\mathrm{F}(3-51)=3.146, \mathrm{p}<.01)$. The mean of scores for posttest $(\bar{X}$ $=17.33$ ) was lower than the mean of scores for pretest $(\bar{X}=19.27)$. However, the mean of scores for follow-up pretest ( $\bar{X}=19.27$ ) was the same as the mean of scores for pretest $(\bar{X}=19.27)$. After the follow-up sessions, the mean of scores for follow-up posttest $(\bar{X}=17.05)$ was lower than the mean of scores pretest $(\bar{X}=19.27)$. This finding indicates that the anger-in scores of students participated in CTAMP were reduced after the experimental process, however it returned to initial state in the first follow-up measurement. It significantly reduced in the final follow-up measurements with the subsequent follow-up sessions; the anger-in scores after the program differed from the measurements results in the subsequent follow-up studies, and the influence of such difference was still present in the follow-up posttest. This indicates that the experimental process reduced the anger-in scores in the long term. 


\section{Discussion, Conclusion and Suggestions}

According to results of research significant differences were found in favor of the experimental group in the mean of scores from STAS for trait anger, anger control, anger-out pretest-posttest while compared to the students in the control group. This finding indicates that CTAMP was effective in reducing the trait anger and anger-out scores and increasing the anger control scores of students in the experiment group. 3-week follow-up sessions were held to determine the long-term influence of psychoeducation program that yielded positive results in the research on reducing anger scores and improving skills for anger control. STAS was re-administrated ten weeks after the end of 12-week education delivered to the experimental group, and then follow-up pretest was performed. The results show that positive effects of CTAMP delivered to the experimental group were maintained. On the other hand, the trait anger and anger-in scores continued to reduce as detected by the follow-up measurements made after follow-up sessions; the increase in the anger control sub-dimension was maintained, and the reduction in the anger-out sub-dimension was also maintained. This may be interpreted that experimental process was effective in reducing the trait anger, anger-in and anger-out scores and increasing the anger control scores. The aggressive behaviors observed across Turkish primary school, high school and university students have a wide range from damaging others or property to self-harm. The preventive services of psychological counseling and guidance address what should individuals do in order to keep individual and social mental health, manage the anger, solve the conflicts, and coop with tendency to aggressiveness-violence. The conflicts of students included in the university life about the academic and social matters mainly concern building interpersonal relationships, becoming distant from their family, and relationship with the opposite sex, and they have difficulty in anger management, which sometimes results in displaying aggressive and violent behaviors. Barefoot, Dahlstrom, and Williams (1983) reported that individuals with less social support showed aggressiveness or hostility. In the meta-analysis study by Nesbit, Conger, and Conger (2007), they found a correlation of 0.40 between the aggressiveness and the anger. From this perspective, the anger leads to occurrence of aggressive reactions when it is not expressed in a healthy or constructive manner (Berkowitz, 1990; Ellis, 1997). Likewise, the literature points out that high level of anger is associated with aggressiveness (Gray, Jackson, \& McKinlay, 1991), and the high level of anger is associated with aggressiveness and tendency to perpetration in the individuals that have committed a crime (McDougall, Venables, \& Roger, 1991). It is reported that the concepts of guilt and shyness are significantly associated with high level of anger and aggressiveness (Tangney, Wagner, Fletcher, \& Gramzov, 1992; Fine \& Olson, 1997) in the university students.

The results from anger-in scores are similar to the results of several studies in the literature (Bedel, 2011; Zorlu, 2017). The individuals that repress their anger may tend to ignore and suppress the negative anger event they have experienced and to restrain themselves (Navaro, 2003, p. 150). When considering the $t$ tests and means together, the situational factors such as force of the environment may have an effect on the anger-in from the perspective of social psychology. This explains that anger-in does not show a linear tendency. From the psychoanalytic view, this may be explained by the fact that individuals always suppress their anger because suppression is an automatic process. Although the groups were heterogenous in the analyses, the number of introverted individuals was high in the groups and this might be caused by the trait of introversion. An individual with anger-in might always be angry with and blame himself/herself, and easily direct his/her anger to himself/herself. It can be said that they have tried coping methods such as crying and making an excuse rather than combatting with the primary cause of anger (Şakiroğlu, 2015, p. 42; Kayaoğlu, 2015, p. 116). Although suppressing the anger may suggest that the problem is perhaps eliminated, actually, the anger is not eliminated and the current problem may be accumulated and continue increasingly. Constantly suppressing and repressing the anger may lead to future physical, psychological (e.g., depression, and psychosomatic disorders) and emotional problems, and to even committing a suicide (Goulston \& Goldberg, 2003, p. 29; Yaman \& Türker, 2011).

It is emphasized that emotions are not strictly dependent on the tendency of reaction, but may be dependent on how to interpret the current conditions (Kustubayeva, Matthews, \& Panganiban, 2012; Martin, 2001). It is underlined that anger management is important in daily life of individuals of different developmental periods studying in different educational stages. The recent researches on the anger management focuses on the programs for developing anger management skills of individuals of different developmental periods. The researchers indicate that people dealing with many increasing problems in the social life may give unpredictable angry and violent-aggressive reactions. With anger management educational programs developed in the light of different theories, the researchers aim at reducing the level of trait anger of individuals, correct expression of anger and acquiring skills for positively controlling the anger. In the literature, the anger management programs appear to be effective that are developed based on different theories and will be used for primary school, secondary school and university students (Yılmaz, 2004; Tekinsav-Sütçü, 2006; Tekinsav-Sütçü, Aydın, \& Sorias, 2010; Eldeleklioğlu \& 
Duran, 2005; Karataş, 2009; Siyez \& Tuna, 2014; Kelleci, Avc1, Erşan, \& Doğan, 2014; Bedel, 2011; Çekiç \& Murat, 2011; Öz \& Aysan, 2011; Serin \& Genç, 2011; Gebeş, 2011; Tuna, 2012; Kıralp, 2013; Özdemir, 2015; Çapacıoğlu \& Demirtaş, 2017; Zorlu, 2017). Thus, the findings in the literature appear to support the findings of this research. In the history of anger management, even people of ancient time gave thought to how to restrain the anger. It is stressed that it is important to receive education at early ages for anger management (Şahin, 2005).

Based on the results obtained from the research, it may be recommended to investigate the influence of anger management skill programs based on different theories on the students of department of PCG in different classes with further studies. The literature indicates that a long-term program is much more effective than a short-term program. Additional reinforcing sessions may be periodically organized with future studies and their long-term influence may be investigated. The Cognitive-Behavioral Techniques may be included in the PCG undergraduate programs in more detail and taught to prospective Psychological Counselors for them to use for group works. Considering that anger is an emotion that prospective psychological counselors are supposed to manage before starting to work, it is considered it would be useful for them to have such an education. Therefore, the psychological counselors have important duties to develop and implement similar programs.

Limitations: This research is limited to the students studying in the department of PCG of Aksaray University. In the research, the participants attended the group works independently of experimental process therefore they were aware that the researcher expected positive behavior changes from them; thus no placebo group was formed to control the influence (Gümüş, 2002) resulting from lack of making a specific effort not to let down such expectation. Another limitation of the research is there was no long-term follow-up measurement. This avoids assessing the longer term influence of the results of research. It is recommended to consider such limitations in further studies.

\section{References}

Barefoot, J. C., Dahlstrom, W. G., \& Williams Jr., R. B. (1983). Hostility, CHD incidence, and total mortality: A 25-year follow-up study of 255 physicians. Psychosomatic Medicine, 45, 59-63. https://doi.org/10.1097/00006842-198303000-00008

Bedel, A. (2011). Kişiler arası sorun çözme beceri eğitiminin ergenlerin sürekli öfke ve öfke ifade tarzlarına etkisinin incelenmesi [Examining the effect of the interpersonal problem solving skills training on the adolescents' trait anger and anger expression styles]. Yayınlanmamıs doktora tezi (Unpublished doctoral thesis). University of Selçuk, Eğitim Bilimleri Enstitüsü, Konya.

Berkowitz, L. (1990). On the formation and regulation of anger and aggression: a cognitive-neoassociationistic analysis. American Psychologist, 45(4), 494-503. https://doi.org/10.1037/0003-066X.45.4.494

Bilge, F. (1996). Danışandan hız alan ve bilişsel yaklaşımlarla yapılan grupla psikolojik danışmanın üniversite ögrencilerinin klzginlık düzeyleri üzerindeki etkileri [The effect of group counseling with client-centered or cognitive-behavioral approach on the anger level of university students]. Yayımlanmamıs doktora tezi (Unpublished doctoral thesis). University of Hacettepe, Sosyal Bilimler Enstitüsü, Ankara.

Büyüköztürk, Ş. (2007). Deneysel desenler (2. Bs). Ankara: Pegem A Yayınları.

Büyüköztürk, Ş. (2008). Sosyal bilimler için veri analizi el kitabı (9. Bs). Ankara: Pegem A. Yayınları.

Çapacıoğlu, G. K., \& Demirtaş, V. Y. (2017). Yaratıcı dramanın ortaöğretim 9. Sınıf öğrencilerinin öfke denetimi becerilerine etkisi [The effects of creative drama over the anger management skills of 9th grade secondry school students]. Illköğretim Online, 16(3), 960-977. https://doi.org/10.17051/ilkonline.2017.330235

Çekiç, A., \& Murat, M. (2011). Grupla psikolojik danışmanın ilköğretim ikinci kademe öğrencilerinin öfke ile başa çıkabilme becerilerine etkisi [The effecets of group counselling on helping anger management skills of second grade students at primary education]. Çukurova Üniversitesi Sosyal Bilimler Enstitüsü Dergisi, 20(3), 41-58.

Çokluk, O., Şekercioğlu, G., \& Büyüköztürk, Ş. (2010). Sosyal bilimler için çok değişkenli istatistik. Ankara: Pegem A. Yayınlar1.

Deffenbacher, J. L., \& Stark, R. S. (1992). Relaxation and cognitive-relaxation treatments of general anger. Journal of Counseling Psychology, 39(2), 158-167. https://doi.org/10.1037/0022-0167.39.2.158

Deffenbacher, J. L., Lynch, R. S., Oetting, E. R., \& Kemper, C. C. (1996). Anger reduction in early adolescents. Journal Of Counseling Psychology, 43(2), 149-157. https://doi.org/10.1037/0022-0167.43.2.149

Deffenbacher, J. L., Mcnamara, K., Stark, R. S., \& Sabadell, P. M. (1990). A comparison of cognitive-behavioral 
and process-oriented group counseling for general anger reduction. Journal of Counseling \& Development, 69(2), 167-172. https://doi.org/10.1002/j.1556-6676.1990.tb01480.x

Efron, R. P. (1997). Her an öfkeli misiniz? [Angry all the time?] (Çev. Semra Eren), Ankara: HYB Yayıncılık.

Eldeleklioğlu, J., \& Duran, Ö. (2005). Öfke kontrol programının 15-18 yaş arası ergenler üzerindeki etkililiğinin araştırılması [Investigation of the efficiency of the anger control programme over 15-18 years old adolescents]. Gazi Ĕ̈itim Fakültesi Dergisi, 25(3), 267-280.

Fine, M. A., \& Olson, K. A. (1997). Anger and hurt in response to provocation: Relationship to psychological adjustment. Journal of Social Behavior and Personality, 12(2), 325-344. Retrieved from http://psycnet.apa.org/record/1997-05013-003

Gebeş, H. (2011). Akran eğitimi ile desteklenen öfke kontrolü ĕgitiminin lise öğrencilerinin öfke kontrol becerilerine etkisi [The effect of peer supported anger managament training program on anger management skills of high school students]. Yayınlanmış yüksek lisans tezi (Unpublished master's thesis). University of Çukurova, Sosyal Bilimler Enstitüsü, Adana.

Glasser, W. (2000). Okulda kaliteli eğitim [The quality school]. İstanbul: Beyaz Yayınları.

Goulston, M., \& Goldberg, P. (2003). Kendi yolunuzdan çekilin (Çevirenler: Betül Çelik, İlkin Özyayla). İstanbul: Sistem Yayıncilık.

Gray, A., Jackson, D. N., \& McKinlay, J. B. (1991). The relation between dominance, anger, and hormones in normally aging men: results from the massachusetts male aging study. Psychosomatic Medicine, 53(4), 375-385. https://doi.org/10.1097/00006842-199107000-00003

Gümüş, A. E. (2002). Sosyal kaygıyla başaçıkma grup programının üniversite öğrencilerinin sosyal kaygı düzeylerine etkisi [The effect of the group program of coping with social anxiety upon social anxiety level of university students]. Yayımlanmamış doktora tezi (Unpublished doctoral thesis). University of Ankara, Sosyal Bilimler Enstitüsü, Ankara.

Harmon-Jones, E. A., \& Harmon-Jones, C. (2007). Anger: Causes and components. In T. A. Cavell, \& K. T. Malcolm (Eds.), Anger, Aggression, and Interventions for Interpersonal Violence (pp. 99-118). New Jersey: Lawrence Erlbaum Associates.

Herrman, D. S., \& McWhirter, J. J. (2003). Anger \& aggression management in young adolescents: An experimental validation of the scare program. Education \& Treatment of Children, 26(3), 273. Retrieved from http://psycnet.apa.org/record/2003-07629-005

Karahan, F., Yalçın, M., \& Erbaş, M. (2014). The beliefs, attitudes and views of university students about anger and the effects of cognitive behavioral therapy-oriented anger control and anxiety management programs on their anger management skill levels. Educational Sciences: Theory \& Practice, 14(6), 2071-2082. https://doi.org/10.12738/Estp.2014.6.2314

Karataş, Z. (2009). Bilişsel davranışçı teknikler kullanılarak yapılan öfke yönetimi programının ergenlerin saldırganlığını azaltmadaki etkisi [The effect of anger management programme through cognitive behavioral techniques on the decrease of adolescents aggression]. Pamukkale Üniversitesi Ë̆itim Fakültesi Dergisi, 26, 12-24.

Kassinove, H., \& Sukhodolsky, D. G. (1995). Anger disorders: basic science and practice issues. In H. Kassinove (Ed.), Anger disorders: definition, diagnosis and treatment (pp. 1-26). Washington, Taylor \& Francis. https://doi.org/10.3109/01460869509087270

Kayaoğlu, M. (2015). Sorular ve örnek vakalarla öfke kontrolü. İstanbul: Nesil Yayınları.

Kelleci, M., Avcı, D., Erşan, E. E., \& Doğan, S. (2014). Bilişsel davranışçı tekniklere dayalı öfke yönetimi programının lise öğrencilerinin öfke ve atılganlık düzeylerine etkisi [Effects of the anger management program based on cognitive behavioral techniques on high school students' anger and assertiveness levels]. Türk Psikiyatri Dizini, 15(4), 296-303. https://doi.org/10.5455/apd.151210

Kıralp, F. S. Ş. (2013). Öfke yönetimi becerileri programının ilkögretim II. Kademe öğrencilerinin öfke düzeylerine etkisi [The effect of the anger management program on the anger levels of the secondary school students]. Yayımlanmamış doktora tezi (Unpublished doctoral thesis). University of Dokuz Eylül, Eğitim Bilimleri Enstitüsü, İzmir.

Köknel, Ö. (2000). Bireysel ve toplumsal şiddet (2. Bs.). İstanbul: Altın Kitaplar Yayınevi. 
Kustubayeva, A., Matthews, G., \& Panganiban, A. R. (2012). Emotion and information search in tactical decision-making: moderator effects of feedback. Motivation and Emotion, 36, 529-543. https://doi.org/10.1016/j.paid.2014.01.029

Martin, L. L. (2001). Mood as Input: A Configural View of Mood Effects. In L. L. Martin, \& G. L. Clore (Eds.), Theories of Mood and Cognition: A User's Guidebook (pp. 135-157). Mahwah, Nj: Lawrence Erlbaum.

McDougall, C., Venables, P., \& Roger, D. (1991). Aggression, anger control and emotion control. Personality And Individual Differences, 12(6), 625-629. https://doi.org/10.1016/0191-8869(91)90260-I

McWhirter, B. T., \& Page, G. L. (1999). Effects of anger management and goal setting group interventions on state-trait anger and self-efficacy beliefs among high risk adolescents. Current Psychology, Developmental Learning, Personality, Social, 18(2), 223-237. https://doi.org/10.1007/s12144-999-1030-2

Navaro, L. (2003). Gerçekten beni duyuyor musun? İstanbul: Remzi Kitabevi.

Nesbit, C. M., Conger, J. C., \& Conger, A. J. (2007). A quantitative review of the relationship between anger and aggressive driving. Aggression and Violent Behavior, 12, 156-176. https://doi.org/10.1016/j.avb.2006.09.003

Olatunji, B. O., Lohr, J. M., \& Bushman, B. J. (2007). The pseudo-psychology of venting in interventions for anger and related conditions: Implications for mental health practice. In T. A. Cavell, \& K. T. Malcolm (Eds.), Anger, Aggression, and Interventions for Interpersonal Violence (pp. 119-142). New Jersey: Lawrence Erlbaum Associates.

Öner, N. (1996). Türkiye'de kullanılan psikolojik testler (2. Basım). İstanbul: Boğaziçi Üniversitesi Matbaası.

Öz F. S., \& Aysan, F. (2011). Öfke yönetimi eğitiminin ergenlerde öfke ile başa çıkma ve iletişim becerilerine etkisi [The Effect of Anger Management Training on Anger Coping and Communication Skills of Adolescents]. International Online Journal of Educational Sciences, 3(1), 343-369.

Öz, F. S., \& Aysan, F. (2012). Öfke yönetimi eğitiminin okul psikolojik danışmanlarının öfkeyle başa çıkma ve güvengenlik becerilerine etkisi [The Effect of Anger Management Training on Anger Coping and Assertiveness Skills of the School Counselors]. Mehmet Akif Ersoy Üniversitesi Sosyal Bilimler Enstitüsü Dergisi, 4(6), 52-69. http://www.dx.doi.org/10.20875/sb.74702

Özdemir, M. B. (2015). Etkinlik temelli grupla psikolojik danışma müdahale programının çocuklarda öfke ve saldırganlığ azaltmaya yönelik etkileri [The impact of activity based group along with psychological consultation and intervention programme to reduce anger and aggression in children]. 21. Yüzyllda Ĕgitim Ve Toplum Dergisi, 4(10), 221-236.

Özer, A. K. (1994b). Sürekli öfke (Sl- öfke) ve öfke ifade tarzı (öfke-tarz) ölçekleri ön çalışması [A serias of studies related to the adaptation of trait anger (T-Anger) and anger expression scales (Anger-EX). Türk Psikoloji Dergisi, 9(31), 26-35.

Özer, A., Erer, Ş., Kocabaş, Z., \& Canberk, A. (1993). “Sinırda” “yüksek” hipertansiyon hastalarının öfke, öfke tarzl, sürekli kaygl, depresyon ve somatizasyon eğilimleri.

Özkamalı, E., \& Buğa, A. (2010). Bir öfke denetimi eğitimi programı'nın üniversite öğrencilerinin sürekli öfke düzeylerine etkisi [The effect of a anger management training program on the anger levels and anger management of university students]. Mersin Üniversitesi Ĕ̈itim Fakültesi Dergisi, 6(2), 50-59. http://www.dx.doi.org/10.17860/efd.61343

Özmen, A. (2004). Seçim kuramına ve gerçeklik terapisine dayalı öfkeyle başa çıkma eğitim programının ve etkileşim grubu uygulamasinın üniversite ögrencilerinin öfkeyle başa çıkma becerileri üzerindeki etkisi [The impact of coping with anger training program based on choice theory and reality therapy and encounter group experience on students skills in coping with anger]. Yayınlanmamış doktora tezi (Unpublished doctoral thesis). University of Ankara, Eğitim Bilimleri Enstitüsü, Ankara.

Rahmatulin, Z. (2015). Bilişsel davranış̧̧ tekniklerle hazırlanan öfke grup terapisinin yetişkin kadınların öfkesi üzerinde etkililiği [Effectıveness of group anger therapy based on cognitıve behavioral techniques on adult women's anger]. Yayımlanmamış yüksek lisans tezi (Unpublished master's thesis). University of Üsküdar, Sosyal Bilimler Enstitüsü. İstanbul.

Şahin, H. (2005). Öfke denetiminin kuramsal temelleri [Theoretıcal bases of anger and anger management]. Süleyman Demirel Üniversitesi Burdur Ë̆itim Fakültesi Dergisi, 6(10), 1-21.

Şakiroğlu, M. (2015). Öfke: Öfkeyi Olumlu Kullanmak. İstanbul: Postiga Yayınları. 
Savaşır, I., \& Şahin, N. H. (1997). Bilişsel davranış̧̧ı terapilerde değerlendirme: Sık kullanılan ölçekler. Ankara: Türk Psikologlar Derneği Yayınları (pp. 71-78).

Serin, B. N., \& Genç, H. (2011). Öfke yönetimi eğitimi programının ergenlerin öfke denetimi becerilerine etkisi [The effects of anger management education on the anger management skills of adolescents]. Eğitim Ve Bilim, 36(159), 236-254.

Shuerger, J. M. (1979). Understanding and controlling anger, helping clients with special concerns (pp.79-102). Boston: Houghton Mifflin Company.

Siyez, M. D., \& Tuna, D. (2014). Lise öğrencilerinin öfke kontrolü ve iletişim becerilerinde çözüm odaklı psiko-eğitim programının etkisi [Effect of solution focused programme on adolescents' anger control and communication skills]. Türk PDR Dergisi, 5(41), 11-22. http://www.dx.doi.org/10.17066/pdrd.48384

Tangney, J. D., Wagner, P., Fletcher, C. \& Gramzow, R. (1992). Shamed into anger? The reletion of shame and guilt to anger and reported aggression. Journal of Personality and Social Psychology, 62(4), 669-675. Retrieved from http://psycnet.apa.org/buy/1992-27250-001

Tekinsav-Sütcü, S. (2006). Ergenlerde öfke ve saldırganlı̆̆ı azaltmaya yönelik bilişsel davranışçı bir müdahale programinin etkililiğinin değerlendirilmesi [Investigation the effect of the cognitive-behavioral group intervention to reducing anger and aggression for adolescents. Yayınlanmamış doktora tezi (Unpublished doctoral thesis). University of Ege, Sosyal Bilimler Enstitüsü, İzmir.

Tekinsav-Sütcü, S., Aydın, A., \& Sorias, O. (2010). Ergenlerde öfke ve saldırganlığı azaltmak için bilişsel davranışçı bir grup terapisi programının etkililiği [Effectiveness of a cognitive behavioral group therapy program for reducing anger and aggression in adolescents]. Türk Psikoloji Dergisi, 25(66), 57-67.

Tuna, D. (2012). Çözüm odaklı kısa süreli yaklaşıma dayalı öfke kontrolü eğitim programının lise ögrencilerinin öfke kontrolü ve iletişim becerileri düzeylerine etkisi [The effect of anger control training program based on prepared solution focused brief approach on high school students' anger control and communication skills]. Yayımlanmamış yüksek lisans tezi (Unpublished master's thesis). University of Dokuz Eylül, Eğitim Bilimleri Enstitüsü, İzmir.

Yaman, E., \& Türker, S. (2011). İlköğretim öğretmenlerinin çatışma yönetim stratejileri ve öfke ifade düzeyleri arasındaki ilişki [Relatıonshıp between prımary school teachers' conflıct management strategy and anger expressing level]. Akademik Bakış Dergisi, 23(1), 1-12.

Yılmaz, N. (2004). Öfke ile başaçıma eğitiminin ve grupla psikolojik danışmanın ergenlerin öfke ile başa çıkabilmeleri üzerindeki etkileri [The effects of anger management training and group counseling on the anger management skills of the adolescent]. Yayımlanmamıs doktora tezi (Unpublished master's thesis). University of Hacettepe, Sosyal Bilimler Enstitüsü, Ankara.

Zajenkowski, M., \& Zajenkowska, A. (2015). Intelligence and aggression: the role of cognitive control and test related stress. Personality and Individual Differences, 81, 23-28. https://doi.org/10.1016/j.paid.2014.12.062

Zorlu, E. (2017). Öfke denetimi eğitim programının lise ögrencilerinin sürekli öfke ve öfke ifade tarzlarına etkisi [The effect og anger management education Program over the high school students'anger and anger state trait]. Yayımlanmamış doktora tezi (Unpublished master's thesis). University of Necmettin Erbakan, Eğitim Bilimleri Enstitüsü, Konya.

\section{Note}

Note 1. This study was presented at the IV ${ }^{\text {nd }}$ International Eurasian Educational Research Congress (EJER 2017, 11-14 May, Denizli-Turkey).

\section{Copyrights}

Copyright for this article is retained by the author(s), with first publication rights granted to the journal.

This is an open-access article distributed under the terms and conditions of the Creative Commons Attribution license (http://creativecommons.org/licenses/by/4.0/). 